\title{
Ophelia roscoffensis Augener, 1910: a new polychaete record in Italian waters
}

\author{
Emanuele Mancini $^{1}$, Francesco Tiralongo ${ }^{2}$, Daniele Ventura ${ }^{3}$, Andrea Bonifazi $^{4}$
}

1 Laboratory of Experimental Oceanology and Marine Ecology, University of Tuscia, Molo Vespucci Porto Commerciale, Civitavecchia, Rome, 00053 Italy. 2 University of Catania, Department of Biological, Geological and Environmental Science, Catania, 95124 Italy. 3 Department of Environmental Biology, University of Rome "La Sapienza", Viale dell'Università 32, Rome, 00053 Italy. 4 Laboratory of Experimental Ecology and Aquaculture, Tor Vergata University, Via della Ricerca Scientifica, Rome, 00133 Italy.

Corresponding author: Emanuele Mancini, e.mancini@unitus.it

\begin{abstract}
Ophelia roscoffensis Augener, 1910 is an opheliid worm identifiable by the number of anterior abranchiate chaetigers and the number of the gill pairs. Although it was already reported in the Mediterranean Sea, it has never been found in the Italian waters. This study represents the first record of Ophelia roscoffensis in the Italian waters. A total of 18 specimens were collected along the coast of Civitavecchia (Tyrrhenian Sea) in a Posidonia oceanica (L.) Delile bed at a depth of $7 \mathrm{~m}$.
\end{abstract}

\section{Keywords}

First record, Italian waters, Mediterranean Sea, Opheliidae, Posidonia oceanica bed, Tyrrhenian Sea.

Academic editor: Ralf Cordeiro | Received 27 February 2019 | Accepted 4 June 2019 | Published 14 June 2019

Citation: Mancini E, Tiralongo F, Ventura D, Bonifazi A (2019) Ophelia roscoffensis Augener, 1910: a new polychaete record in the Italian waters. Check List 15 (3): 489-495. https://doi.org/10.15560/15.3.489

\section{Introduction}

The family Opheliidae Malmgren, 1867 (Annelida, Scolecida) includes 5 genera and over 120 species (Magalhães et al. 2019). The most recent studies on the systematics of this family have shown that the genus Travisia Johnston, 1840 belongs to a separate family, Travisiidae Hartmann-Schröder, 1971 (Blake and Maciolek 2016b). Additionally, Blake and Maciolek (2016b) considered Ammotrypanella McIntosh, 1878, Tachytrypane McIntosh in Jeffreys, 1876, and Antiobactrum Chamberlin, 1919 as synonyms of Ophelina. The Opheliidae are usually grouped with Scalembregmatidae Malmgrem, 1987 (Rouse 2001), and there is no apomorphy supporting the monophyly of Ophelidae, as noted by Fauchald and
Rouse (1997). The members of this family are typically sedentary burrowers, commonly found on sandy and muddy substrates (Fauvel 1927, Fauchald 1977, Rouse 2001, Maciolek and Blake 2006); their distribution in different substrates show specific patterns that are closely related to the granulometry of the sediments (Maciolek and Blake 2006). The opheliids have separate sexes, and some species become pelagic as sexually mature epitokes (Maciolek and Blake 2006). They usually show a fusiform body, characterized by a low number of segments (30-60) and by the presence of a ventral groove along the whole body. The prostomium is conical and without appendages; an anterior palpode and a pair of posterior nuchal organs are usually present. The peristomium is reduced and fused with the prostomium. The parapodia 
are all morphologically similar and biramous, with small button-shaped parapodial lobes. The dorsal and the ventral cirri are usually absent, and the chaetae are all capillary, either smooth or marginally dentate. The pygidium usually bears numerous papillae (Malmgrem 1867, Fauvel 1927, Fauchald 1977, Parapar 2012).

In the European Register of Marine Species (Costello et al. 2001), 28 species of opheliids were reported, belonging to 9 genera. But, after the most recent taxonomic revisions (Brewer et al. 2011, Blake and Maciolek 2016a, 2016b, Magalhães et al. 2019, Read and Fauchauld 2019a), only 26 species belonging 5 genera are currently considered as valid: Armandia Filippi, 1861, Ophelia Savigny, 1822, Ophelina Örsted, 1843, Polyophthalmus Quatrefages, 1850, and Thoracophelia Ehlers, 1897. Along the Italian coasts, 4 genera and 14 species are currently reported (Castelli et al. 2008) and the genus Ophelia Savigny, 1822 is represented by 5 species: Ophelia amoureuxi Bellan \& Costa, 1822, O. barquii Fauvel, 1927, O. bicornis Savigny, 1822, O. limacina (Rathke, 1843), and O. traslucens (Katzmann, 1973) (Castelli et al. 2008).

The genus Ophelia, which includes 38 species, is recognized by a fusiform body organized in 2 regions: an anterior cylindrical region and a posterior region furrowed by a deep ventral groove. The branchiae are present and located starting from 2 to 10 chaetigers (Malmgrem 1867, Fauvel 1927, Fauchald 1977, Maciolek and Blake 2006, Parapar 2012). Ophelia roscoffensis Augener, 1910 is a cylindrical worm with a body length up to $50 \mathrm{~mm}$ and a maximum of 32 segments. This species is identifiable by the presence of branchiae on the posterior body region and by the number of abranchiate anterior chaetigers (8) (Fauvel 1927, Parapar 2012). Moreover, Tebble (1952) has described a tegumentary structure that characterizes the posterior region of this species: in the last 4 segments (including anal segment), 2 pairs of sinuous lateral ridges are present, which enclose 3 dorsal grooves.

Ophelia roscoffensis was originally described by Augener (1910) based on specimens from the French Atlantic coast at Roscoff. In European waters, it has been found in the English Channel and along the North-East Atlantic coasts of France, Spain, and Portugal (Tebble 1952, 1953, Bellan 1964, Dauvin et al. 2003, Costello et al. 2001, Ramos 2010, Read and Fauchald 2019b). In the Mediterranean Sea it has been reported along the coasts of Spain, Greece (Simboura 1996, Zenetos et al 1997, Ramos 2010, Faulwetter et al. 2010, 2017), and Turkey (Çinar et al. 2014). The specimens of O. roscoffensis were collected from a shallow-water Posidonia oceanica (L.) Delile bed along the coast of Civitavecchia (central Tyrrhenian Sea) during scuba surveys performed in 2015 and 2016. All 18 specimens of O. roscoffensis were found in association with the polychaetes Goniadella bobrezkii (Annenkova, 1929) and Acromegalomma messapicum (Giangrande \& Licciano, 2008) and with the isopod Mesanthura sp.; all these species were recently reported, for the first time in the Northern Tyrrhenian sea, in the same $P$. oceanica meadow (Tiralongo et al. 2017, Giangrande et al. 2018, Mancini et al. 2019).This study represents the first record of Ophelia roscoffensis in the Italian waters.

\section{Methods}

The specimens of Ophelia roscoffensis were collected along the coast of Civitavecchia (northern Tyrrhenian Sea), near the harbour (Fig. 1). Scuba surveys were performed during 2015 and 2016, in the months of October, March, May, and August, on sandy pools, located at a depth of about $7 \mathrm{~m}$ on a Posidonia oceanica bed. Samples were collected by means of corers. Following Gambi et al. (1998) and Buia et al. (2003), each PVC tube corer was $10 \mathrm{~cm}$ in diameter and $25 \mathrm{~cm}$ long (surface area $=78.5 \mathrm{~cm}^{2}$ ) with a $0.4 \mathrm{~mm}$ mesh net on top. Corers were plunged into the sediment to a depth of $20 \mathrm{~cm}$. At each sampling, 5 replicates were collected and sieved with a mesh size of $0.5 \mathrm{~mm}$. The retained fraction of sediment was subsequently preserved in $4 \%$ buffered formalin. In the laboratory, all organisms were sorted and identified to the finest taxonomic level possible (i.e. species) and subsequently preserved in $75 \%$ ethanol. The morphological features and the diagnostic characteristics of $O$. roscoffensis specimens were examined following Augener (1910), Fauvel (1927), Tebble (1952), and Parapar (2012). The material was deposited in the marine invertebrate collection of Laboratory of Experimental Oceanology and Marine Ecology, University of Tuscia (Civitavecchia, Roma: CL-02-POS-17).

Ophelia limacina (SB-155-POS-14-17), preserved in the zoological collection of the Laboratory of Experimental Oceanography and Marine Ecology (University of Tuscia, Viterbo), was used for morphological comparison with $O$. roscofensis specimens.

\section{Results}

New records. Italy: Civitavecchia (Rome) (42.0844 $\mathrm{N}, 011.7990^{\circ} \mathrm{E}, 7 \mathrm{~m}$ depth), Emanuele Mancini, October 2015 (2 specimens), March 2016 (3 specimens), May 2016 (5 specimens), August 2016 (8 specimens).

Environmental characteristics. In the study area, the Posidonia oceanica bed extends at depths from approximately 3-18 $\mathrm{m}$. The meadow architecture shows a fragmented coverage: live $P$. oceanica cover $69 \%$ of the seabed, $17 \%$ is covered by coarse sand, and $14 \%$ consists of small rocks. The $P$. oceanica density remains quite constant throughout the year, with a density of 260312 shoots $/ \mathrm{m}^{2}$ (Paladini De Mendoza et al. 2018). The unvegetated areas were mostly represented by circular sandy patches of 1-6 $\mathrm{m}$ in diameter. In the sandy patches the sediment is composed by gravelly coarse sand; the gravel fraction (19-60\%) mainly consisted of bioclasts composed by skeletal fragments and shells. The coastal site has moderate to high wave conditions. The wave 


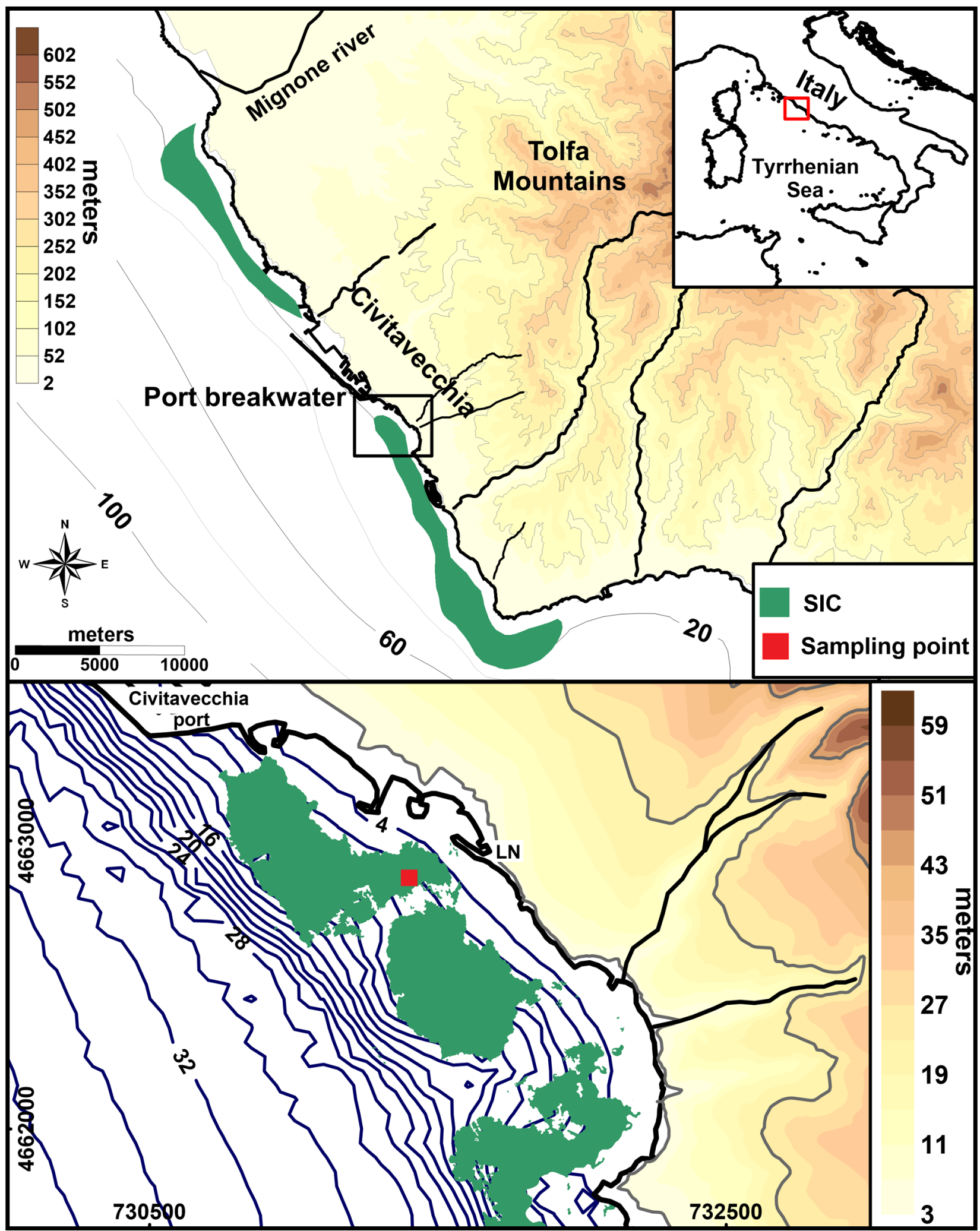

Figure 1. Map of study area with location of sampling site (SCl: Site of Community Importance "Posidonia oceanica meadows").

climate exhibits a seasonal fluctuation, with a maximum during autumn and winter $(1.5-3 \mathrm{~m})$ and a minimum in summer (0.5-1.5 m) (Paladini De Mendoza et al. 2018). In late summer, $P$. oceanica begins to shed leaves, which progressively covers the seafloor with leaf litter. The leaf litter remains on the seafloor until the first storm, which transports away a large part of the litter (Paladini De Mendoza et al. 2018).
Identification. The specimens were assigned to the genus Ophelia based on the following morphological characteristics: fusiform body organized externally into 2 regions, an anterior cylindrical region and a posterior region furrowed by a deep ventral groove; prostomium conical; proboscis globose and smooth; branchiae cirriformes, starting from 8th-11th segment; parapodia with reduced rami; chaetae all simple capillaries; pygidium 


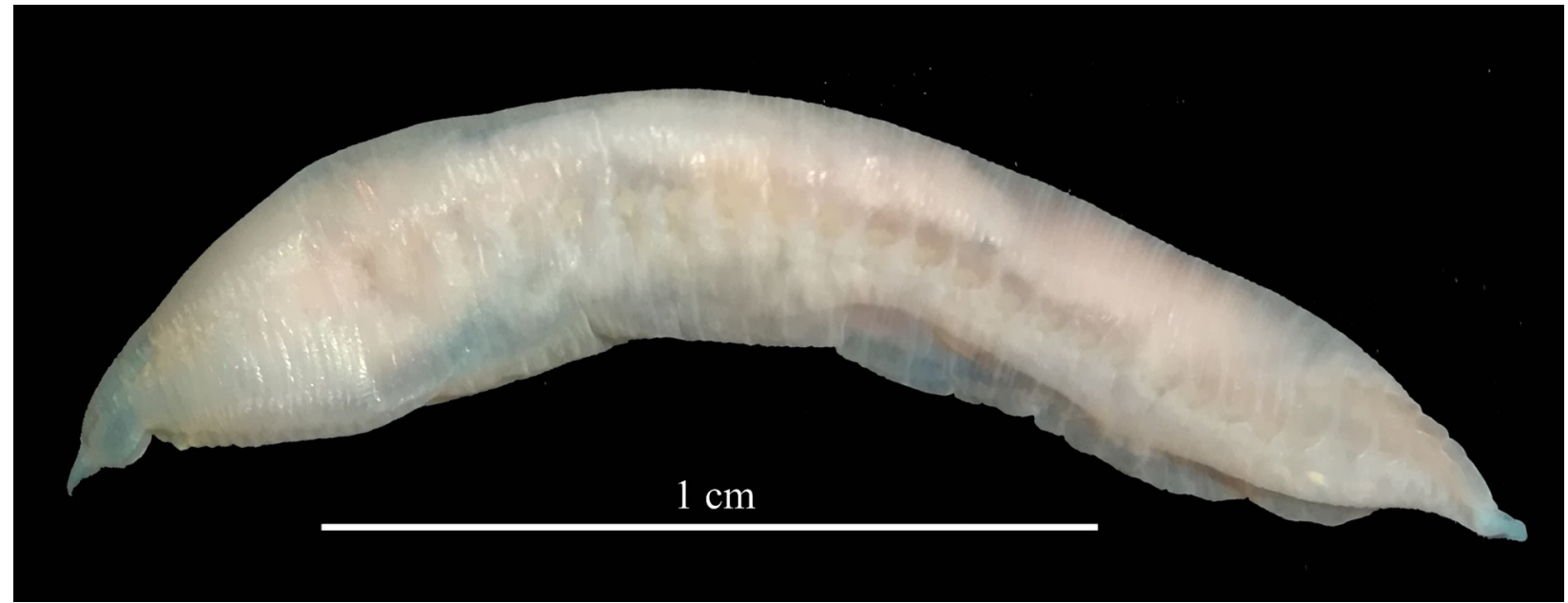

Figure 2. Ophelia roscoffensis (CL-02-POS-17). Lateral view of whole animal.
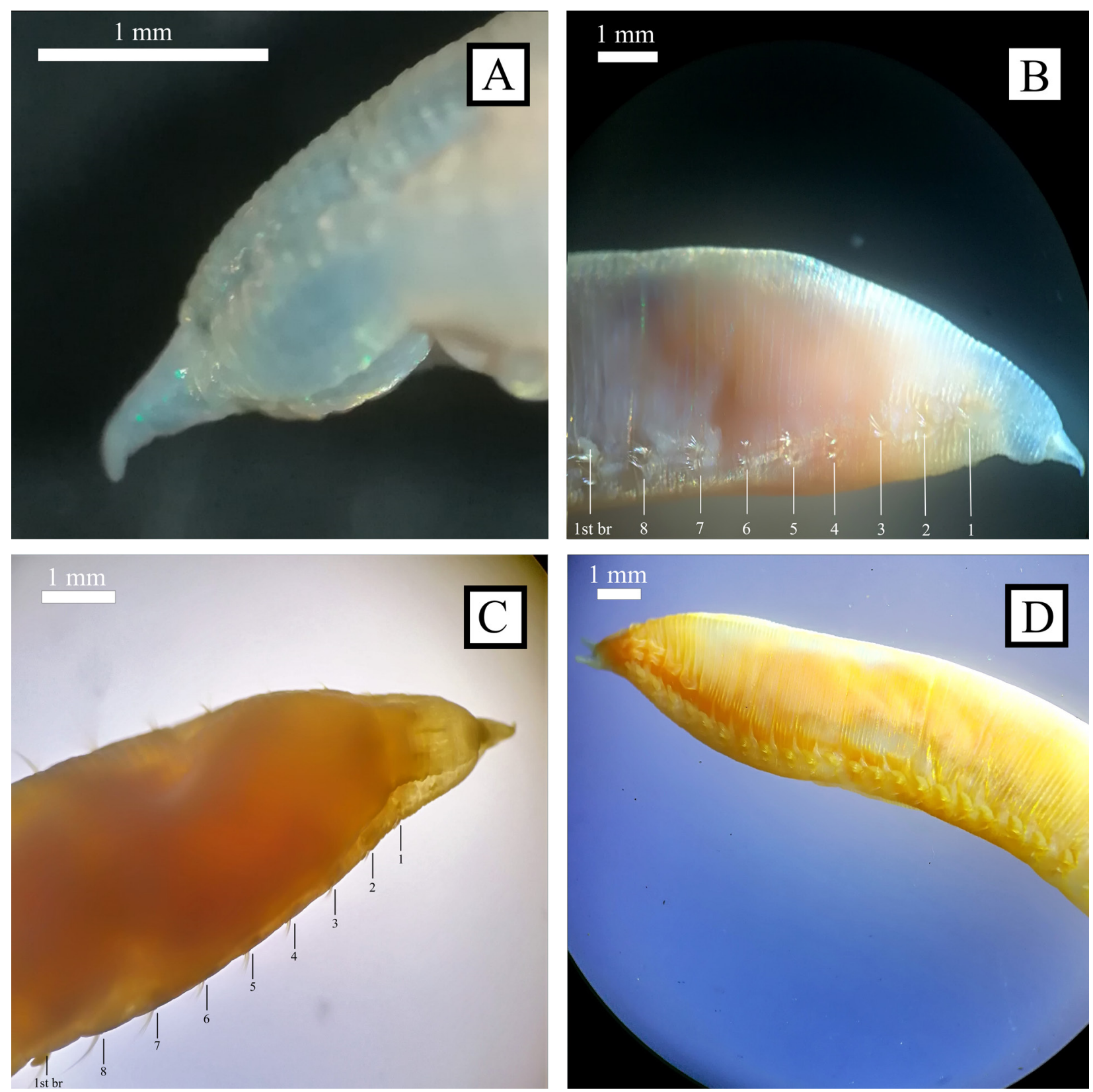

Figure 3. Ophelia roscoffensis (CL-02-POS-17). A. Lateral view of head. B. Lateral view of anterior region (1-8: anterior abranchiate chaetigers; 1st br: first branchia). C. Dorsal view of anterior region (1-8: anterior abranchiate chaetigers; 1st br: first branchia). D. Lateral view of posterior region. 

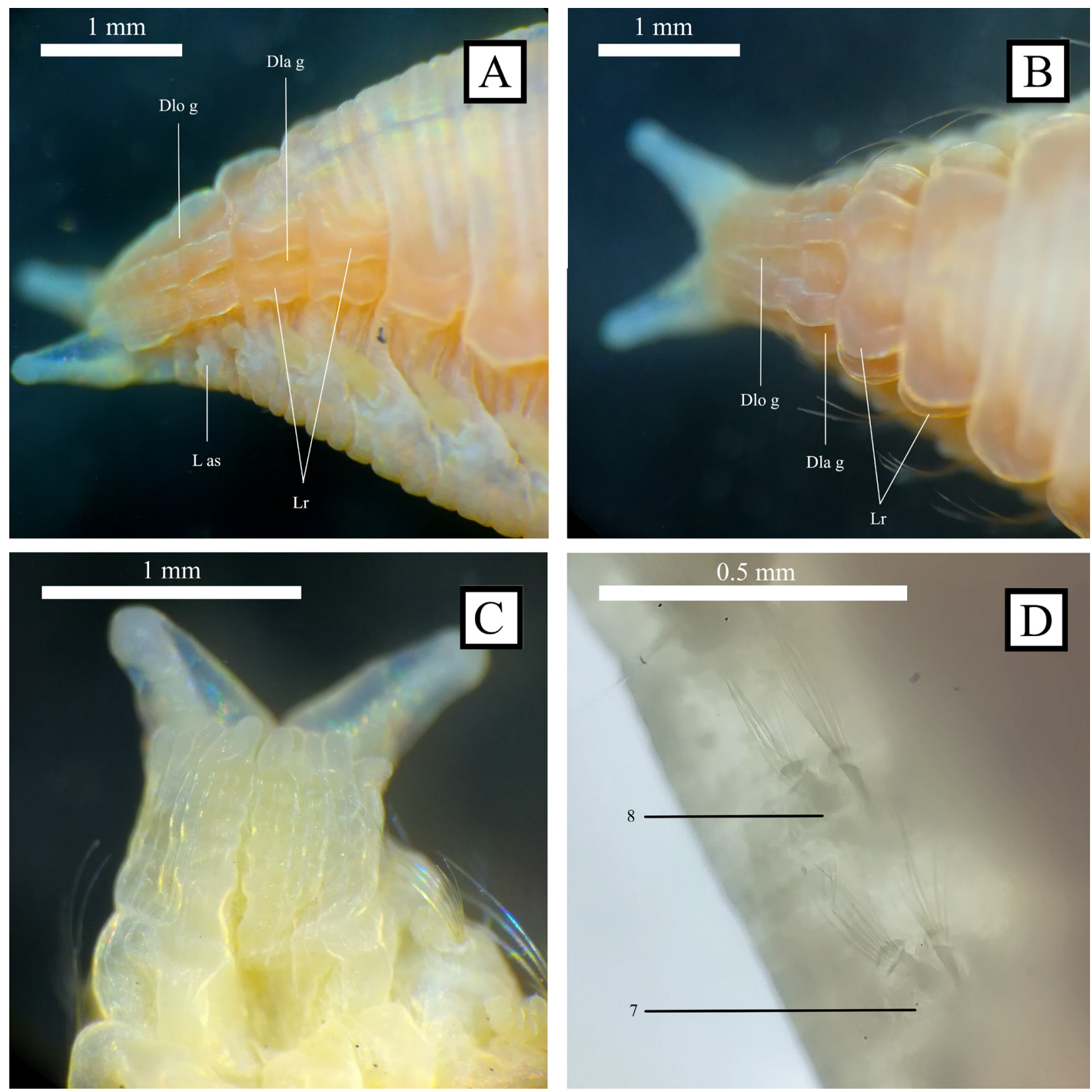

Figure 4. Ophelia roscoffensis (CL-02-POS-17). A. Lateral view of posterior tegumentary structures (Dlo g: dorsal longitudinal groove; Dla g: dorso-lateral groove; L as: last abranchiate chaetiger; Lr: lateral ridges). B. Dorsal view of posterior tegumentary structures (Dlo g: dorsal longitudinal groove; Dla g: dorso-lateral groove; Lr: lateral ridges). C. Dorsal papillae. D. Chaetigers 7 and 8.

with 1 or 2 ventral papillae and several smallest dorsal papillae (Augener 1910, Fauvel 1927, Parapar 2012). The specimens were subsequently identified as $O$. roscoffensis based on the presence of 8 anterior abranchiate segments, 32 segments, and 23 branchiae (Augener 1910, Fauvel 1927, Parapar 2012) and on the analysis of the posterior tegumentary structures that start from the 28th chaetiger (Tebble 1952).

Description. The 18 collected specimens were 12.1$27.5 \mathrm{~mm}$ long with 32 chaetigers; the last chaetiger is abranchiate (Fig. 4A). The body is pale pink after preservation (Fig. 2) and organized externally into 2 regions (Fig. 2): an anterior abranchiate cylindrical region with 8 chaetigers (Fig. 3B, C) and a posterior region characterized by the presence of a deep ventral groove (Fig. 3D).
Twenty-three pairs of cirriforme branchiae are present in the posterior region (Fig. 3D). The prostomium is conical, pointed, and has no appendages (Fig. 3A). The proboscis is globose and smooth. The parapodia are reduced and with button-shaped parapodial lobes (Fig.4D). The chaetae are all simple and capillary (Fig. 4D). The pygidium bears 2 large ventral papillae and 12 smaller dorsal papillae arranged in 2 small circles (Fig. 4C). The posterior tegumentary structures are present starting from the 28th chaetiger and extending up to the 32nd chaetiger (Fig. 4A, B). This dermal structure is produced by 2 pairs of sinuous lateral ridges that enclose 3 dorsal grooves: 2 dorso-lateral grooves and 1 dorsal longitudinal groove (Fig. 4A, B).

The specimens showed a constant increase in body length from autumn (12.1-16.1 $\mathrm{mm})$, through winter 
(16.8-17.3 mm) and spring $(17.1-18.5 \mathrm{~mm})$, to summer (19.7-27.5 mm).

In the same scuba surveys, 3 other species sampled were found for the first time in the Northern Tyrrhenian Sea: the polychaetes Acromegalomma messapicum (Giangrande \& Licciano, 2008). and Goniadella bobrezkii and the isopod Mesanthura sp. (Tiralongo et al. 2017, Giangrande et al. 2018, Mancini et al. 2019).

\section{Discussion}

This study represents the first record of Ophelia ruscoffensis in Italian coastal waters and only the fourth record in Mediterranean waters. According to the literature, in the Mediterranean Sea, the species has been reported from Spanish (Ramos 2010), Greek (Simboura 1996, Zenetos et al. 1997, Faulwetter et al. 2010, 2017), and Turkish waters (Çınar et al. 2014). In the Atlantic Ocean, it has been reported from the English Channel (Dauvin et al. 2003) and along the coasts of France, Spain, and Portugal (Tebble 1952, 1953, Bellan 1964, Costello et al. 2001, Dauvin et al. 2003, Iberfauna 2013, Read and Fauchauld 2019b).

Augener (1910 in Fauvel 1927) described Ophelia ruscoffensis as a variant of $O$. limacina based on observations of a specimen with fewer anterior abranchiate chaetigers. Tebble (1952) proposed the separation of these taxa into 2 species after observing several differences in the arrangement of the segments, the construction of the posterior tegumentary structure, the number of anterior abranchiate segments, and the number of dorsal papillae. Our morphological comparison between the 2 species also showed that the posterior tegumentary structure was clearly different between them. Instead, the number of the anterior abranchiate segments and the number of branchiae pairs were less clear and more difficult to determine after preservation in alcohol. For this reason, the analysis of the posterior dermal structures is a more reliable method for the distinction between these 2 species.

The increase in the number of individuals in May and August could be related to the lowest wave intensity and to the greater stability of the bed sediments observed in spring and summer for this area (Paladini De Mendoza et al. 2018). Furthermore, the increment of organic matter in the sediments, favoured by the growth phase of $P$. oceanica, could explain the constant size increase of individuals during the year. During late summer, the $P$. oceanica leaf litter, deposited on the unvegetated bed, increased the concentration of organic matter in the bed sediments with a consequent increase in trophic resources for non-selective deposit-feeders (Fauchauld and Jumars 1978, Danovaro and Fabiano 1995, Manini et al. 1997). Moreover, the leaf litter buffers seabed particles, preventing the resuspension processes and generating a greater stability in the seafloor substrates (Paladini De Mendoza et al. 2018).

In accordance with the previous observation by
Bellan (1964) that described this species in association with the coarse sand, our individuals were collected on gravelly coarse sand characterized by the presence of a high percentage of shells and skeletal fragments. Specimens of Ophelia roscoffensis were collected in association with 3 other species recently reported in the Northern Tyrrhenian Sea: Acromegalomma messapicum, Goniadella bobrezkii, and Mesanthura sp. (Tiralongo et al. 2017, Giangrande et al. 2018, Mancini et al. 2019). These new records of all 4 species in the same $P$. oceanica meadow, highlight the role of this phanerogam as biodiversity hotspot.

Our work increases the knowledge about the distribution and ecology of this species in the Mediterranean Sea.

\section{Acknowledgements}

We are thankful to Dr Francesco Paladini De Mendoza for his support during the sampling operations and for his contribution in the analysis and description of the environmental characteristics of the study area. We also thank Yueyun Wang and Edgar Uriel Garduño Montes de Oca for providing valuable comments, which have improved the quality of the manuscript.

\section{Authors' Contributions}

EM collected (scuba diver) and identified the specimens, wrote the manuscript and prepared the map. FT collected (scuba diver) the specimens and wrote the manuscript. DV photographed (stereo and optical microscope) the specimens and revised the manuscript. AB examined the specimens, wrote, revised, and approved the manuscript.

\section{References}

Augener H (1910) Bemerkungen über einige Polychaeten von Roscoff, über zwein eue Polynoiden des Berliner Museums, und über die Brutpflege von Hipponoe gaudichaudi Aud. \& M. Edw. Zoologischer Anzeiger 36: 232-249.

Bellan G (1964) Contribution à l'étude systématique, bionomique et écologique des annélides polychètes de la Méditerrannée. PhD thesis. Universitéd'Aix-Marseille, Marseille, 371 pp.

Blake JA, Maciolek NJ (2016a) Opheliidae Malmgren, 1867. In: Westheide W, Purschke G (Eds) Handbook of Zoology. De Gruyter, Berlin, 10 pp. https://www.degruyter.com/view/Zoology/bp_029 147-6 74. Accessed on: 2019-18-05.

Blake JA, Maciolek, NJ (2016b) Travisiidae Hartmann-Schröder, 1971, new family status. In: Westheide W, Purschke G (Eds) Handbook of Zoology. De Gruyter, Berlin, 10 pp. http://www.degruyter.com/ view/Zoology/bp_029147-6_75. Accessed on: 2019-18-05.

Brewer MS, Sierwald P, Bond JE (2011) A generic homonym concerning chordeumatid millipedes (Arthropoda: Diplopoda) and ophellid worms (Annelida: Polycheata). Zootaxa 2744 (1): 65-68. http://doi.org/10.11646/zootaxa.2744.1.6

Buia MC, Gambi MC, Dappiano M (2003) I sistemi a Fanerogame marine. Biologia Marina Mediterranea 10: 145-198.

Castelli A, Bianchi CN, Cantone G, Çinar ME, Gambi MC, Giangrande A, Iraci Sareri D, Lanera P, Licciano M, Musco L, Sanfilippo R, Simonini R (2008) Annelida Polychaeta. Checklist della 
flora e della fauna dei mari italiani. Biologia Marina Mediterranea $15: 323-373$.

Çinar ME, Dağlı E, Kurt ŞG (2014) Check-list of Annelida from the coasts of Turkey. Turkish Journal of Zoology 38: 1-31. https://doi. org/10.3906/zoo-1405-72

Costello MJ, Emblow CS, White R (Eds) (2001) European register of marine species. A check-list of the marine species in Europe and a bibliography of guides to their identification. Patrimoines Naturels 50: 1-463.

Danovaro R, Fabiano M (1995) Seasonal and inter-annual variation of bacteria in a seagrass bed of the Mediterranean Sea: relationship with labile organic compounds and other environmental factors. Aquatic Microbial Ecology. 9: 17-26.

Dauvin JC, Dewarumez JM, Gentil F (2003) Liste actualisée des espèces d'annélides polychètes presents en Manche. Cahiers de Biologie Marine 44 (1): 67-95.

Fauchald K (1977) The polychaete worms. Definitions and keys to the orders, families and genera. Natural History Museum of Los Angeles County, Science Series 28: 1-188

Fauchauld K, Jumars PA (1979) The diet of worms: a study of polychaete feeding guilds. Oceanography and Marine Biology: an Annual Review 17: 193-284.

Fauchauld K, Rouse GW (1997) Polychaeta systematics: past and present. Zoologica Scripta 26: 71-138.

Faulwetter S (2010) Check-list of marine Polychaeta from Greece. Aristotle University of Thessaloniki. Assembled in the framework of the EU FP7 PESI project. http://www.marinespecies.org/ aphia.php? $\mathrm{p}=$ sourcedetails\&id=142069. Accessed on: 2019-18-05

Faulwetter S, Simboura N, Katsiaras N, Chatzigeorgiou G, Arvanitidis C (2017) Polychaetes of Greece: an updated and annotated checklist. Biodiversity Data Journal 5: e20997. https://doi.org/10.3897/ BDJ.5.e20997

Fauvel P (1927) Polychètes sédentaires. Addenda aux errantes, archiannélides, myzostomaires. Faune de France 16: 1-494.

Gambi MC, Conti G, Bremec CS (1998). Polychate distribution, diversity and seasonality related to seagrass cover in shallow bottoms of the Tyrrhenian Sea (Italy). Scientia Marina 62 (1-2): 1-17.

Giangrande A, Mancini E, Tiralongo F, Licciano M (2018) Addition to the knowledge on Acromegalomma messapicum (Giangrande \& Licciano, 2008) (Annelida: Sabellidae). The European Zoological Journal 85 (1): 55-63. https://doi.org/10.1080/24750263.2018.143 7227

Iberfauna (2013) Species Ophelia roscoffensis. Augener, 1910. In Iberfauna: el Banco de Datos de la Fauna Ibérica. Museo Nacional de Ciencias Naturales. http://iberfauna.mncn.csic.es/showficha.aspx? rank=T\&idtax=6642. Accessed on: 2019-6-5.

Magalhães WF, Rizzo AE, Bailey-Brock JH (2019) Opheliidae (Annelida: Polychaeta) from the western Pacific islands, including five new species. Zootaxa 4555 (2): 209-235. https://doi.org/ 10.11646/zootaxa.4555.2.3

Malmgren AJ (1867) Annulata Polychaeta: Spetsbergiae, Groenlandiae, Islandiae et Scandinaviae hactenus cognita. Ex Officina Frenckelliana, Helsingfors, 127 pp., 115 pls.
Maciolek NJ, Blake JA (2006) Opheliidae (Polychaeta) collected by the R/V Hero and the USNS Eltanin cruises from the Southern Ocean and South America. Scientia Marina 70 (S3): 101-113. https://doi.org/10.3989/scimar.2006.70s3101

Mancini E, Tiralongo F, Ventura D, Bonifazi A (2019) Goniadella bobrezkii (Annenkova, 1929) (Annelida, Polychaeta): first record in the Italian waters. Check List 15 (1): 125-130. https://doi.org/ $10.15560 / 15.1 .125$

Manini E, Danovaro R, Pusceddu A, Fabiano M (1997) Biochemical composition of sedimentary organic matter and bacterial dynamics in sandy and seagrass sediments of the NW Mediterranean. In: Piazzo M (Ed.) Proceedings XII ${ }^{\text {th }}$ Congresso Associazione Italiana di Oceanologia e Limnologia. A.I.O.L., Genova, 87-95.

Paladini De Mendoza F, Fontolan G, Mancini E, Scanu E, Scanu S Bonamano S, Marcelli M (2018) Sediment dynamics and resuspension processes in shallow-water Posidonia oceanica meadows. Marine Geology 404: 174-186. http://doi.org/10.1016/j. margeo.2018.07.006

Parapar J (2012) Familia Opheliidae Malmgren, 1867. In: Parapar J Alós C, Núñez J, Moreira J, López E, Aguirrezabalga F, Besteiro C, Martínez A (Eds) Annelida Polychaeta III. Fauna Ibérica 36. Consejo Superior de Investigaciones Cientificas, Madrid, 284-310.

Read G, Fauchald K (Ed.) (2019a). World Polychaeta database Opheliidae Malmgren, 1867. Accessed through: World Register of Marine Species at: http://www.marinespecies.org/aphia. $\mathrm{php}$ ? $\mathrm{p}=$ taxdetails\&id=924. Accessed on: 2019-25-02 .

Read G, Fauchald K (Ed.) (2019b). World Polychaeta Database. Ophelia roscoffensis Augener, 1910. Accessed through: World Register of Marine Species. http://www.marinespecies.org/aphia. php? $\mathrm{p}=$ taxdetails\&id=130497. Accessed on: 2019-25-02.

Rouse GW (2001) Opheliidae Malmgren, 1867. In: Rouse GW, Pleijel F (Eds) Polychaetes. Oxford University Press, Oxford, 53-56.

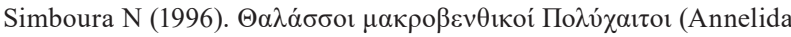

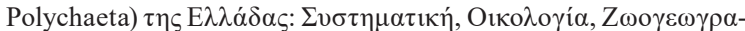
pía [Marine Macrobentic Polychaetes (Annelida Polychaeta) of Greece: Systematic, Ecology, Zoology]. PhD thesis, National and Kapodistrian University of Athens, Athens, 241 pp. [in Greek].

Tebble N (1952) On three species of the genus Ophelia (Polychaeta) from British and adjacent waters. Annals and Magazine of Natural History 5 (54): 553-571.

Tebble N (1953) A review of the genus Ophelia (Polychaeta) with descriptions of new species from South African and Californian waters. Annals and Magazine of Natural History 6 (65): 361-368.

Tiralongo F, Paladini De Mendoza F, Mancini E (2017) On the estabilishment of Mesanthura (Isopoda: Anthuridae) in the northern Tyrrhenian sea and notes about its ecology. In: New Mediterranean Marine Biodiversity Records. Mediterranean Marine Science 18 (3): 534-556. https://doi.org/10.12681/mms.15823

Zenetos A, Christianidis S, Pancucci AM, Simboura N, Tziavos C (1997) Oceanographic study of an open coastal area in the Ionian Sea with emphasis on its benthic fauna and some zoogeographical remarks. Oceanologica Acta 202 (2): 437-451. 